\title{
THE NEED FOR AN ANTIDUMPING MARKET STRUCTURE TEST IN THE CONTEXT OF FREE TRADE AGREEMENTS
}

\author{
Charles M. Gastle and James Leach ${ }^{*}$
}

In October, 1999, the Standing Committee on Foreign Affairs and International Trade of the Canadian House of Commons issued a report entitled: The Free Trade Area of the Americas: Towards a Hemispheric Agreement in the Canadian Interest ("Standing Committee Report").' Surprisingly, the Standing Committee Report contains a recommendation that Canada should resist the merging of antidumping provisions with antitrust predatory pricing provisions.

The Committee's understanding of the issue is that predatory pricing and antidumping were born out of different necessities and intentions. The former provisions were conceived to protect the interests of consumers, with the objective of securing a competitive process for the longer term. The latter provisions were conceived to protect domestic producers from a specific foreign rival with special circumstances enabling it to discriminate between markets. Often these circumstances are protected domestic markets.

In the case of antidumping, the interests of consumers are being subordinated to those of domestic producers. When viewed in this light, the Committee is of the opinion that competition policy and its administrative authority should never be put in the position of subordinating the interests of consumers to those of producers. However, without the permanent disappearance of the ability to discriminate between domestic and foreign markets, there are indeed circumstances in which the interests of domestic producers should prevail over those of consumers, but not in all instances. Provided that proper administrative discretion is exercised in the application of antidumping provisions, the Committee concludes that there is no valid reason, or political appetite for that matter, for folding antidumping into antitrust. Competition and antidumping policies should, for the time being, remain separate. ${ }^{2}$

* Charles Gastle, B. Comm., LL.B., LL.M., D.Jur. obtained a Doctor of Jurisprudence Degree in international trade from Osgoode Hall Law School, Toronto, and is a member of the Ontario Bar and partner at Shibley Righton, Toronto. James Leach is the former Canadian Ambassador to Peru and Bolivia and is now the Executive Director of the Estey Centre for Law and Economics in International Trade. The authors wish to acknowledge the research assistance provided by Thomas Humbert, a graduate law student from Aix-Marseille University in France.

1. STANDING COMM. ON FOREIGN AFFAIRS AND INT'L TRADE OF THE CANADIAN HOUSE of Commons, The Free Trade area of the americas: Towards a Hemispheric AGREEMENT IN THE CANADIAN INTEREST (1999), at http://www.parl.gc.ca/infocomdoc/36/2/ fait/studies/reports/faitrp01/30-ch15-e.html.

2. Id. at Ch.15: Competition Policy and Law. 
The Government of Canada's response report ("Government Response") ${ }^{3}$ adopted this surprising position:

The Government supports the recommendation of the Committee to resist merging anti-dumping provisions with predatory pricing provisions in competition policy and law. Rather, the Government will continue its efforts to seek improvements to the application and operation of antidumping systems in the hemisphere in the context of a separate Negotiating Group on Subsidies, Antidumping and Countervailing Duties. ${ }^{4}$

Canadian international trade policy now appears to embrace antidumping practices, albeit with some modifications to the underlying antidumping rules. This marks a rejection of at least fifteen years of Canadian trade policy seeking the elimination of antidumping practices. Canada's reversal in trade policy is unprincipled and seems to suggest that its trading interests are better served by maintaining protectionist mechanisms which it can use against its trading partners. This change in trade policy suggests that Canada has begun to view itself differently in terms of world trade and not with the same sense of vulnerability to perceived misuse by the United States of its contingent trade regime. In the context of the Free Trade Agreement of the Americas ("FTAA") initiative - where this change in trade policy occurred - it appears that Canada wants to retain this trade weapon with respect to imports from the emerging nations in Central and South America.

In this article, it is respectfully submitted that Canadian trade policy has become muddled, at a time when American abandonment of a position of leadership in trade liberalization gives an opportunity to eliminate antidumping practices, at least on an interim basis in negotiations to broaden hemispheric free trade. Canadian trade policy had the correct focus when negotiating its free trade agreement with Chile ${ }^{5}$ in 1997 that provided for the elimination of antidumping practices no later than $2003 .^{6}$ This precedent should be followed in the free trade agreement with Costa Rica that was under consideration at the time of writing.

3. See DEPT. OF FOREIGN AFFAIRS AND INT'L TRADE (CANADA), GOV'T RESPONSE TO THE REPORTOFTHE STANDING COMMITTEE ON FOREIGN AFFAIRS AND INT' L TRADE - "THEFREE TRADE AREA OF THE AMERICAS: TOWARDS A HEMISPHERIC AGREEMENT IN THE CANADIAN INTEREST," at http://www.dfait-maeci.gc.ca/tna-nac/FTAAreport-full-e.asp (last visited Mar. $15,2000)$.

4. Id.

5. See Canada-Chile Free Trade Agreement, Dec. 5, 1996, Canada-Chile, 36 I.L.M. 1067 (1997), available at http://www.dfait-maeci.gc.ca/tna-nac/cda-chile/chap-m26.asp [hereinafter CCFTA].

6. Id. art. $\mathrm{M}-03$. 
In the alternative to the elimination of antidumping practices, the commitment to open markets represented by free trade agreements, such as the North American Free Trade Agreement (NAFTA), ${ }^{7}$ justifies, at minimum, a qualification or limitation upon the traditional antidumping duty practices. It is submitted that, at the very least, a market structure test should be imposed requiring complainants in proceedings involving a free trade agreement party to establish that some specific market impediment exists which gives rise to an ability to differentiate between the exporter's home market and the complainant's import market, resulting from a lack of efficiency. ${ }^{8}$ Some artificial impediment (such as a border restriction) or anticompetitive conduct would have to be shown, which keeps the home market price high.

This article starts with a review of antidumping practices and then provides an analysis indicating the nature of the presumption made by antidumping practices that a market impediment exists where there is a difference between the home and target market price. The concept of a market structure test is then discussed, as it was developed during the evolution of American antitrust principles over the past thirty years. The article then makes a proposal regarding the manner in which a market structure test might be used to qualify antidumping practices in the context of free trade agreements such as NAFTA, thus resulting in a somewhat more economically rational international trade law remedy. Of course, this article should not be seen as an endorsement of this alternative as the principle route of reform. The "first-best" reform is to eliminate antidumping practices entirely.

In the context of bilateral trade between the United States and Canada, the complainant-import jurisdiction might utilize its own competition law in determining whether a private practice constitutes an actionable market impediment. If the United States is taken as an example, the American administrative tribunals would be required to use the recoupment test in the context of discriminatory and predatory pricing doctrine, established by the Brooke Group ${ }^{9}$ precedent. In the context of the FTAA, however, it is not possible to allow each jurisdiction to utilize its own competition law. This is due to the early stage of development of competition law institutions in the Central American and South American jurisdictions or relative lack of experience with competition law concepts. We recommend that the Brooke

7. See North American Free Trade Agreement, Dec. 17, 1992, United States, Mexico, Canada, 32 I.L.M 605 (1993), available at http://www-tech.mit.edu/Bulletins/nafta.html [hereinafter NAFTA].

8. Throughout this paper we will use the terms "export-home market" and "complainantimport market." In a proceeding in the United States to impose antidumping duties on Canadian products, Canada would be the export-home market and the United States would be the complainant-import market. 1993).

9. Brooke Group Ltd. v. Brown \& Williamson Tobacco Corp., 113 S.Ct. 2578 (U.S. 
Group recoupment test be integrated directly into the free trade agreement with respect to antidumping disputes between free trade members. Antidumping practices have been subject to rigorous international trade law rules established by international agreements. Therefore, the addition of a market structure test at the international level follows a well-established precedent. More importantly, inclusion of basic antitrust concepts within an international agreement will provide valuable experience to jurisdictions with newly established competition law institutions.

With respect to public practices, we recommend that a traditional market barrier, such as a tariff, would automatically meet the market structure test, and antidumping duties would be available if the traditional requirements can be established. The difficult question is how more subtle public practices should be treated, and a mere difference in the regulatory environments should not be sufficient. We recommend that the complainant should have the burden of proof to establish that the particular public practice acts as an artificial barrier to entry that permits the respondent to discriminate between the export-home market and the complainant-import market. The complainant should also have the obligation to show that the discrimination in question has allowed the respondent to realize supracompetitive profits in the export-home jurisdiction.

We conclude with a discussion of the appropriate remedy. We recommend that in the case of private practices, bi-national panels be given the authority to enjoin the impugned private practice, if they are given the ability to review the findings of administrative tribunals on a de novo basis. With respect to public practices, it is recommended that the bi-national panels have the authority to order the removal of the practice in question. Again, this would require the bi-national panels to have the ability to review the final determinations of administrative tribunals on a de novo basis. In the alternative, the bi-national panels should have the authority to vacate the antidumping duty order if the respondent government eliminates the impugned public practice.

\section{CANADA'S EPIPHANY AND ABANDONMENT OF ITS TRADITIONAL POLICY OBJECTIVE}

The Standing Committee Report is correct in its statement that predatory pricing and antidumping principles pursue different objectives; the former promotes consumer welfare and the latter promote producer welfare. The Committee suggests that there are circumstances in which antidumping principles are justifiable and the one example cited involves protected domestic markets. No explanation is given as to when the ability to discriminate should allow an abandonment of the competition law objective of promoting lower prices, which is what "consumer welfare" actually means. Of course, one might point out that the objective of a "free trade agreement" is to eliminate the ability to discriminate between markets based 
on the fortuitous existence of a border interposed between the two markets. The question goes unanswered as to why the antidumping mechanism should be maintained in circumstances where the free trade negotiations have been successful in eliminating tariffs and other barriers between the markets. The Committee also fails to explain what other factors allow discrimination between markets and why they should justify the maintenance of the antidumping mechanism when competition law provisions address discriminatory pricing domestically, while maintaining its objective of promoting consumer welfare.

The passage in the Standing Committee Report (quoted above) is remarkable because it suggests that the merging of predatory pricing and antidumping principles would put the competition tribunal in the position of "subordinating the interests of consumers to producers." This is simply incorrect, as the merging of the two disciplines would result in one set of predatory or discriminatory pricing principles that would promote consumer welfare. The role of the competition tribunal and the courts would not change at all.

At what point in the establishment of free trade does the antidumping mechanism become redundant? In the past, the Canadian government took the position that the establishment of free trade should be sufficient to justify the elimination of the mechanism. At the time of the Canada-United States Free Trade Agreement (CUSFTA) ${ }^{10}$ negotiations in 1987, the negotiating objective was to eliminate the antidumping mechanism in favor of competition law principles.

Dumping was a less intractable problem. At the suspension of negotiations, Canada had rejected a U.S. proposal to set up a working group to examine the feasibility of relying on competition laws after the transition period as a substitute for antidumping law. In Canada's view, such a technical group had concluded its work over the course of the summer. It had considered all aspects of the problem and prepared a number of technical papers. Canadian experts were satisfied that it would be feasible to rely on competition policy at the end of the transition period and to implement a special regime based on competition principles during that transition. The 22 September U.S. proposal was its first formal response. The United States was not prepared to commit itself to the development of a regime based on domestic competition law, it was only ready to explore the issue. The U.S. proposal also did not address the possibility 
of changes in the existing antidumping regime for the duration of the transition period. ${ }^{1}$

And further,

We had tried for months to find some basis for meeting legitimate American concerns while protecting our interests. ... As far as the Americans were concerned, the status quo was just fine. American firms were generally not bankrupted by Canadian anti-dumping duties that covered only a small percentage of their total sales. . . .

For many Canadian exporters, this was literally a matter of economic life or death. Many of our firms shipped half or more of their production to the United States. They had structured their operations around that market as the best way to achieve the volumes needed to increase their revenues and lower their costs. This would be all the more true after a free trade agreement eliminated the tariffs at the border. If, the moment they were successful in exporting to the United States, their American competitors could haul them before a kangaroo court, tie them up in interminable, prohibitively expensive litigation, and very possibly get penalties applied to all imported shipments, these companies would be wiped out. Or they would be forced to move their investment, with the production and jobs, south of the border to escape these penalties.

Obviously, our first choice would be to get rid of the unfair trade laws entirely. Alternatively, we would want Canada to be "exempted" from these laws, to use the prime minister's phrase. Neither of these options was in the cards. ${ }^{12}$

The theory supporting the elimination of the antidumping mechanism was that once tariffs and other barriers were removed there would be no ability to use pricing strategies that could take advantage of protected markets. Thus, firms would be expected to follow pricing strategies falling

11. Michael HaRT, DeCision at Midnight: INSide the CaNADA-US FREE-TRADE NEgOtIATIONS 300 (1994). See also Michael Hart, Dumping and Free Trade Areas, in ANTIDUMPING LAW AND PRACTICE 326 (Jackson and Vermulst eds. 1989); Debra Steger, Dispute Settlement, in TRADE-OFFS ON FREE TRADE: THE CANADA-US FREE TRADE AGREEMENT 182 (Marc Gold and D. Leyton-Brown eds. 1988).

12. GoRdon Ritchie, Wrestling With The Elephant, The Inside StORY OF THE CANADA-US TRADE WARS 100-01 (1997). 
within the "ambit of domestic law regulating restrictive business practices." 13 The importance of this objective was reflected in the Canada-United States Free Trade Agreement (CUSFTA), Article 1906:

The provisions of this Chapter shall be in effect for five years pending the development of a substitute system of rules in both countries for antidumping and countervailing duties as applied to their bilateral trade. If no such system of rules is agreed and implemented at the end of five years, the provisions of this Chapter shall be extended for a further two years. Failure to agree to implement a new regime at the end of the two-year extension shall allow either party to terminate the Agreement on six-months notice. ${ }^{14}$

While the threat to terminate the agreement was an empty inducement, the provision underscored the importance of the elimination of the antidumping duty mechanism at that time, at least as a political issue within Canada.

The traditional Canadian position that the antidumping mechanism should be eliminated was the basis for the trade negotiations with Chile. The Canada-Chile Free Trade Agreement (CCFTA) included the following provision:

Article M-01: Reciprocal Exemption from the Application of Antidumping Duty Laws

1. Subject to Article M-03, as of the date of entry into force of this Agreement each Party agrees not to apply its domestic antidumping law to goods of the other Party. Specifically:

(a) neither Party shall initiate any antidumping investigations or review with respect to goods of the other Party;

(b) each Party shall terminate any ongoing antidumping investigations or inquiries in respect of. such goods;

(c) neither Party shall impose new antidumping duties or other measures in respect of such goods; and

(d) each Party shall revoke all existing orders levying antidumping duties in respect of such goods. ${ }^{15}$

13. Michael Hart, Dumping and Free Trade Areas, in ANTIDUMPING LAW ANDPRACTICE 326 (Jackson and Vermulst eds. 1989).

14. See CUSFTA, supra note 10

15. CCFTA, supra note 5 art. M-01. 
Article M-03 is a phase-in provision requiring the elimination of antidumping provisions on the date when the tariff of both Parties is eliminated for the particular good in question, or by January 1, 2003, whichever comes first. ${ }^{16}$ We submit that these provisions are consistent with the traditional Canadian trade position and with one that is principled.

In light of this history, the acceptance of the antidumping mechanism in the Standing Committee Report and the Government Response, must be seen as a significant change in Canadian trade policy. Given the treatment of the issue by the Standing Committee, the question arises whether the elimination of antidumping and countervailing duty practices are justified only in cases where "perfect" economic integration exists in the form of a fully developed customs union. Alternatively, one might question whether these remedies should be qualified at some mid-point between separately evolving economies and a fully integrated customs union.

NAFTA $^{17}$ is not a customs union, and there are a number of remaining impediments to full economic integration. One example of such an impediment is the lack of freedom of cross-border labor movement, but American trade negotiators would also point to a number of factors such as restrictions in Canada intended to protect its culture. ${ }^{18}$ Both Canada and the United States now appear to agree that these impediments justify the continuing existence of the traditional World Trade Organization (WTO) trade remedies in all international trade disputes. At the same time, the objective of NAFTA was to eliminate trade barriers by January $1,1998 .{ }^{19}$ The degree of economic integration of the United States and Canada is quite remarkable, and the degree of openness of the Canadian economy contrasts sharply to that of a number of other economies, such as Japan.

16. See id. art.M-03.

17. NAFTA, supra note 7.

18. See United States Trade Representative, 2000 National Trade Estimate Repon on Foreign Trade Barriers, available at www.ustr.gov/reports/nte/2000/contents.html. This report provides a list of alleged barriers to trade. They include: supply management in dairy products; eggs and poultry; restrictions on horticultural imports and non-agricultural goods; barriers to film exports; certain reciprocity rates in its Copyright Act; restrictions pursuant to the Broadcasting Act imposing Canadian content performance standards; Canadian ownership requirements in basic telecommunications services; and certain investment restrictions. See id. at 30-36.

19. See NAFTA, supra note 7. 


\section{CANADIAN EXPOSURE TO FOREIGN COMPETITION \\ (Percentage basis) $^{20}$}

$\begin{array}{llll}\text { Manufacturing } & \begin{array}{l}\text { Food, beverages } \\ \text { and tobacco }\end{array} & \begin{array}{l}\text { Textiles, } \\ \text { footwear } \\ \text { leather }\end{array} & \begin{array}{l}\text { Wood \& } \\ \text { Wood } \\ \text { Products }\end{array}\end{array}$

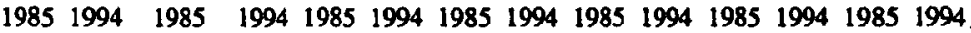

$\begin{array}{lrrrrrrrrrrrrrr}\text { United States } & 18.8 & 27.7 & 8.9 & 11.1 & 22.9 & 36.5 & 11.1 & 14.7 & 6.6 & 9.1 & 15.5 & 21.7 & 13.3 & 12.5 \\ \text { Canada } & 58.5 & 73.8 & 19.8 & 28.4 & 33.5 & 51.2 & 47.8 & 80.1 & 47.2 & 60.2 & 37.8 & 60.4 & 21.7 & 39.8 \\ \text { Japan } & 18.5 & 17.4 & 7.1 & 8.6 & 18.0 & 22.7 & 7.8 & 14.4 & 4.2 & 3.3 & 14.9 & 14.2 & 8.6 & 8.2 \\ \text { Total OECD } & 32.6 & 38.0 & 28.5 & 21.7 & 38.7 & 49.3 & 20.7 & 25.2 & 16.9 & 19.7 & 32.8 & 36.8 & 25.5 & 30.0\end{array}$

While "perfect" economic integration in the form of a customs union does not exist, the question arises why Canada is subject to the same trade remedies as Japan, when it has made a much more profound commitment to an open market which can be easily confirmed across a broad range of market segments. Does this commitment only warrant a different form of judicial review (prescribed by the bi-national panel established by Chapter 19 of NAFTA) of final antidumping and countervailing duty determinations? ${ }^{21}$

It is respectfully submitted that NAFTA's commitment to open markets justifies the elimination of or, at a minimum, a limitation upon the traditional antidumping duty mechanism. It appears to be based upon a presumption that if the requisite difference in the home and target prices is demonstrated, some artificial market impediment exists that is not based upon efficiency. Alternatively, using the wording of the Standing Committee Report, there must be some factor based on the existence of an international border permitting the foreign producer to discriminate between the export-home market and the complainant-import market which, once again, is not based on efficiency. Where no such factor can be identified, the fundamental justification for imposing duties is lacking because an open, competitive, and efficient market apparently exists. The higher home market price - if not resulting from the byzantine methods by which costs are constructed according to antidumping principles - must be due to some factor related to efficiency. If not, a competitive opportunity likely exists, which the complainant's manufacturers have not exploited in the exporter's home market. Higher prices in the home market should attract entry and the remedy is a pro-competitive one - the complainant should compete and attempt to penetrate the exporter's home market - instead of wasting

20. OECD, SCIENCE, TECHNOLOGY, AND INDUSTRY, SCOREBOARDOF INDICATORS, 173 (1997). This comparison is based on the export share of production within a sector, combined with a weighted average of the import share of domestic consumption.

21. See NAFTA, supra note 7, ch. 19. 
resources on litigation or seeking the imposition by government of deadweight consumer welfare losses through antidumping duties.

With respect, the reversal of Canadian policy is in error, and the elimination of the mechanism contained in the CCFTA is the proper policy position; this requires the abandonment of the antidumping mechanism. In the absence of an artificial impediment, the Standing Committee's logic, and that of the government, requires that no antidumping duty be imposed. There is no policy justification for imposing higher prices upon consumers and deadweight losses upon the Canadian economy.

\section{The Presumption by Antidumping Practices of a MARKET IMPEDIMENT}

The Agreement on Implementation of Article VI of the General Agreement on Tariffs and Trade, 1994 (Antidumping Agreement) ${ }^{22}$ provides that a product is to be considered as dumped (i.e., introduced into the commerce of another country at less than its normal value) if the export price from one country to another is less than the comparable price for the like product when destined for consumption in the exporting (home) country. ${ }^{23}$ The Antidumping Agreement provides for a bifurcated tribunal mechanism. Separate administrative agencies decide whether dumping has occurred and whether injury has been sustained. In the United States, the Department of Commerce determines the margin of dumping, and the International Trade Commission determines injury. ${ }^{24}$

The Antidumping Agreement provides that provisional duties (usually in the form of a security by way of cash deposit or bond) may be demanded within sixty days of the commencement of the investigation where a preliminary affirmative determination of dumping and consequent injury has been made. $^{25}$ The standard for imposing provisional duties is low and effectively places a reverse onus upon the foreign exporter. The United States' implementing legislation requires the International Trade Commission to determine if "there is a reasonable indication that the requisite injury exists. ${ }^{26}$

22. See Agreement on Implementation of Article VI of the General Agreement on Tariffs and Trade, annex 1A, H.R. Doc. No. 316, 103d Cong. (1994) reprinted in LEGAL INSTRUMENTS-RESULTS OF THE URUGUAY ROUND, available at http://www/wto.org/english/docs_e/legal_e/final_e.html [hereinafter Antidumping Agreement].

23. See id. art. 2.1.

24. In Canada, the corresponding agencies are the Deputy Minister of National Revenue for Customs and Excise, and the Canadian Import Trade Tribunal (CITT). See NAFTA, supra note 7 , at annex 1911.

25. See Antidumping Agreement, supra note 22, arts. 7.1, 7.2, 7.3.

26. JOSEPH E. PATTISON, ANTIDUMPING ANDCOUNTERVAILING DUTY LAWS 3-13 (1984); see also Tariff Act of 1930, $\S 4,19$ U.S.C.A § 1677 (2000). 
The Commission held that the test requires a negative determination only when: (1) the record of a proceeding contains clear and convincing evidence of no material injury or threat thereof; and (2) no likelihood exists that evidence demonstrating material injury for threat thereof will surface in the final investigation. ${ }^{27}$

After provisional duties have been imposed, the investigating authority must verify all information upon reaching a final determination with respect to its finding of dumping. ${ }^{28}$ The comparison between the export price and the normal value is to be made at the ex-factory level, and due allowance is to be made for differences which affect price comparability, including differences in conditions and terms of sale, taxation, levels of trade, quantities, and physical characteristics. ${ }^{29}$ Using American practice as an example, the Department of Commerce obtains substantial information regarding the foreign and domestic markets through sales questionnaires. Initially, information regarding the corporate structure is obtained, including the description of the units involved in the development, manufacture, sale, and distribution of merchandise under investigation. ${ }^{30}$ The Department requests lists of the ten largest shareholders and the percentage of ownership each controls. ${ }^{31}$ Commerce also demands a flow chart and description of each method or channel of distribution for the American and export-home markets. For each, the functions performed and services offered ${ }^{32}$ in each distribution channel to each customer or class of customer in the United States and export-home markets. With respect to the sales process, the Department of Commerce seeks detailed information on each sale in the United States and export-home markets during the period of investigation, including sales agreements and price lists, along with discount or rebate schedules. ${ }^{33}$ The Department of Commerce also obtains information regarding accounting and financial practices, including a chart of accounts, audited consolidated and unconsolidated financial statements, and internal financial statements or profit and loss reports. ${ }^{34}$

In short, the Department of Commerce obtains a complete description of the export-home and United States markets, including the pricing and the profitability thereof. The power given to the investigating agencies is significant, notwithstanding the fact that they. lack subpoena power in the foreign jurisdiction. Foreign exporters are encouraged to cooperate and

27. See PATtison, supra note 26 , al 3-14.

28. See id. at 8-1 (citing 19 U.S.C.A. $\$ 1677 \mathrm{~m}$ (i) (2000)).

29. See id. art. 2.4 .

30. See id. at appendix M, § A.2.a.

31. See id. at appendix $M, \S A .2 . d$.

32. See id. at appendix M, § A.3.b. These lists include inventory maintenance, technical advice, warranty and other after sales service, freight and delivery arrangements, after-sale warehousing, and advertising or other sales support facilities. See id.

33. See id. at appendix $M, \S A .3 .4$.

34. See id. at appendix M, $\S$ A.6. 
provide the required information. If they refuse access to or otherwise do not provide necessary information within a reasonable period of time or significantly impede the investigation, the determination can be made on the basis of the "best information available." 35 When the investigating authorities resort to best information available, it often means the facts contained in the originating complaint.

Where the export price is non-existent or unreliable, the export price may be constructed on the basis of the price at which the imported products are first sold to an independent buyer, or if the products are not resold to an independent buyer or not resold in the condition as imported, then on such reasonable basis as the authorities may determine. ${ }^{36}$ The investigating authorities conduct a constructed cost analysis, in which they build the socalled "normal value" by analyzing all of its constituent components, including an allocation for profit. ${ }^{37}$ Allowances are to be made on the basis of a fully-allocated cost standard, with due allowance for costs and profits. ${ }^{38}$

A finding of dumping alone is not sufficient to impose duties; the investigators must also determine that the dumping has caused injury. The injury determination must be based "on positive evidence and involve an objective examination of both: (a) the volume of the dumped imports and the effect of the dumped imports on prices in the domestic market for like products, and (b) the consequent impact of these imports on domestic producers of such products. ${ }^{39}$ The Department of Commerce must determine whether there has been significant price undercutting by the dumped imports as compared with the price of a like product, "or whether the effect of such imports is otherwise to depress prices to a significant degree or to prevent price increases, which otherwise would have occurred, to a significant degree. ${ }^{40}$ The Antidumping Agreement provides that the investigating authority is to consider various factors concerning the domestic industry:

The examination of the impact of the dumped imports on the domestic industry concerned shall include an evaluation of all relevant economic factors and indices having a bearing on

35. Antidumping Agreement, supra note 22, art. 6(8), annex II.

36. See id. art. 2.3

37. Past practice was to estimate an eight percent margin but this was changed in the 1994 WTO Agreements to check pattem in the industry. See RICHARD BOLTUCK AND ROBERT E.

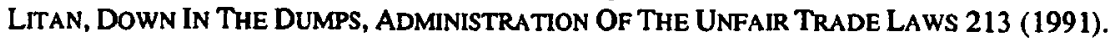

38. Antidumping Agreement, supra note 22, art. 2.4. As indicated below, lawmakers debated the appropriate cost standard in the context of predatory pricing provisions in antitrust law. The debate has been bracketed by a marginal cost standard versus a fully-allocated cost standard. The antidumping price standard is beyond a fully-allocated cost standard because the home market "normal value" includes not only an allocation of all costs but also provide for a reasonable profit in the circumstances. See infra pp. 53-68.

39. Id. art. 3.1.

40. Id. art. 3.2 . 
the state of the industry, including actual and potential decline in sales, profits, output, market share, productivity, return on investment, or utilization of capacity; factors affecting domestic prices; the magnitude of the margin of dumping; actual and potential negative effects on cash flow, inventories, employment, wages, growth, ability to raise capital or investments. This list is not exhaustive, nor can one or several of these factors necessarily give decisive guidance."

Investigators must find a causal relationship between the dumping and the domestic injury. This is based on the examination of all relevant evidence. before the authorities, who are required to examine "any known factors other than the dumped imports which at the same time are injuring the domestic industry, and the injuries caused by these other factors must not be attributed to the dumped imports. ${ }^{42}$ These factors might include contraction in demand or changes in the patterns of consumption, trade restrictive practices and/or competition between the foreign and domestic producers, developments in technology, and the export performance and productivity of the domestic industry. ${ }^{43}$

In the United States, the International Trade Commission obtains detailed information relevant to the determination of injury or a material threat thereof, through the issuance of detailed questionnaires, including information related to export shipments of the merchandise by the producer. ${ }^{44}$ The Tariff Act requires the Commission to consider the following factors when making its injury determination: volume of imports, the effect of imports on the subject merchandise on prices in the United States for the like product, and the impact of imports of the subject merchandise on domestic producers of like products. ${ }^{45}$ The Tariff Act defines material injury as "harm

41. Id. art. 3.4.

42. $l d$. art. 3.5 .

43. See id.

44. See PATTISON, supra note 26 , at 4-4. The questionnaire focuses upon injury to the domestic industry regarding production, sales, pricing, employment, capacity and utilization issues from both the importers and U.S. producers of the subject merchandise. It requests information related to the following issues, among others: (1) total production broken down by producing plant location and product type; (2) quantity and value of imports; (3) export shipments of the merchandise by the producer; (4) hours worked by production and production related employees in producing all products; (5) total wages paid to production and production related employees; (6) comparison of price and quantities; (7) changes in ability to raise capital and investment; (8) increases or decreases in working capital; and (9) average selling prices and production costs; among a wide variety of other information sought. See id. at 4-6-4-8.

45. See Tariff Act, 19 U.S.C. $\$ 1677(7)$ (B). The commission is directed to evaluate five factors including: (1) actual and potential decline in output, sales, market share, profits, productivity return on investments and utilization of capacity; (2) factors affecting domestic 
which is not inconsequential, immaterial or unimportant. ${ }^{n 6}$ Injury determinations in the United States indicate that certain evidence in particular contributes to a positive finding. Pricing trends are important, and the Commission is required to weigh the two basic aspects of pricing referred to above, whether there has been significant price undercutting and/or price depression or suppression. ${ }^{47}$ "Import sales at prices substantially below those of domestic producers often substantially sway the Commission in its injury findings." ${ }^{48}$ It is irrelevant whether the price underselling or undercutting is of a "predatory" nature. ${ }^{49}$ Another key factor is market share, but the Commission is more interested in the dynamics of the market share and an increase therein than by the magnitude of market penetration by imports. ${ }^{50}$ Of somewhat lesser importance are issues of profitability and domestic employment factors, along with capacity utilization. ${ }^{51}$

There are a number of presumptions in antidumping practices that highlight the difference between competition and international trade law. For instance, antidumping practices appear to prohibit cross-subsidization between markets if the requisite degree of injury can be found. From the standpoint of international trade law, a foreign exporter should not be allowed to earn profits in the export-home market to subsidize sales in the complainant-import market. It does not matter whether pricing in the complainant-import market exceeds its marginal costs, thus indicating that the foreign exporter is acting in an economically rational manner.

Another identifiable presumption is that there is price inelasticity in the relevant pricing range in the export-home market. Prices are maintained at artificially high levels in the exporter's home market, and this is possible because the market segment in question is not unduly price sensitive. In other words, the demand for the product remains relatively constant notwithstanding the higher prices in the export-home market, or at least the increase in price exceeds the decrease in sales caused by the higher prices. If the home market exhibited price elasticity (i.e., if any price increase would cause a correspondingly greater decrease in sales volume due, for instance,

prices; (3) actual and potential negative effects on cash flow, inventories, employment, wages, growth, ability to rise capital, and investment; (4) actual and potential negative effects on the existing development and production efforts of the domestic industry, including efforts to develop a derivative or more advanced version of the like product; and (5) the magnitude of the dumping margin. See 19 U.S.C. \& $1677(7)(C)$. No one factor is determinative and the Commission is not restricted to these factors. See PATtison, supra note 26, at 4-9 (citing 19 U.S.C. \& 1677(7)(F)(ii)).

46. PatTison, supra note 26 , at 4-7.

47. See id. at 4-8.

48. Id. at 4-15; see also BIC Corp. v. United States, 19 I.T.R.D. 1560 (Ct.Int'l Trade 1997); Companhia Paulista de Ferro Ligas v. United States, 18 I.T.R.D. 1542 (Ct.Int'I.Trade 1996).

49. See PATTISON, supra note 26 , at 4-14.

50. See id. at 4-12.

51. See id. at 4-15 - 4-19. 
to readily available substitutes) the maintenance of higher prices would not be economically rational. Profits would decrease in the home market.

This leads into the most important presumption for the standpoint of this article - the presumption that antidumping practices of a market impediment allow the foreign exporter to exploit the export-home market in a manner not available to the domestic industry in the complainant-import market. In the Canadian context, this means that the Canadian exporter can exploit the Canadian market in a manner not available to its American competitors. Such a presumption must exist because, if no such impediment is present, why has the American manufacturer simply not supplied the Canadian market? The higher prices in the Canadian market should attract market entry if they are not a result of manipulation sanctioned by constructed price analyses and other nuances of antidumping practices.

The presumption of a market impediment is evident in certain aspects of the antidumping practices that were reviewed above. It is seen in the insular focus of the investigation of injury in the domestic market on such factors as domestic market share, profitability, production capacity, and utilization of technology, among others. There is no explicit requirement to give consideration to the export performance of the domestic industry, particularly from the standpoint as to what efforts, if any, have been made in attempting to penetrate the export-home market to take advantage of the higher prices. There is no inquiry into the reasons for the difference in price evident in the export-home and the complainant-import market. The existence of the price difference itself becomes the market structure analysis. Nothing more is needed as the injury requirement appears to provide the element of causation.

\section{COMPETITION LAW AND ITS EVOLUTION TO A MARKET STRUCTURE TEST}

The importance of the presumption of a market impediment when a difference in pricing exists between the export-home and the complainantimport market becomes apparent when one considers the manner in which similar issues are treated in the context of antitrust law. The possibility of subsidization between markets is considered irrelevant, absent anticompetitive conduct. The issue of a market structure that is conducive to the exploitation of the impugned pricing practice, becomes the focal point of the analysis.

Traditionally, competition law regulated competition within a market, and trade policy regulated trade between markets. Ostensibly, both are concerned with the conditions of trade within a particular jurisdiction, but they start from fundamentally different premises. Antitrust has shifted to a predominantly efficiency and consumer welfare orientation, but countervailing duty and antidumping laws embrace a producer-welfare orientation. This difference in orientation begins to break down once 
markets integrate. The question becomes what degree of integration is necessary such that the difference in orientation is no longer justified?

Antidumping principles find their counterpart in the predatory pricing and price discrimination provisions of the American antitrust statutes. Section 2 of the Sherman Act ${ }^{52}$ deals with predatory pricing in the context of attempts at monopolization and provides:

Every person who shall monopolize, or attempt to monopolize, or combine or conspire with any other person or persons, to monopolize any part of the trade or commerce among the several States, or with foreign nations, shall be deemed guilty of a felony . . . ${ }^{53}$

In the context of predatory behavior, the complainant must prove that the alleged monopolist has the market power or the prospect of acquiring market power sufficient to drive competitors out of the market, with the ability to then raise prices through a restriction of output allowing recoupment of the losses. The circumstances in which these factors can be established are considered to be relatively rare.

Section 2(a) of the Clayton Act, ${ }^{54}$ as amended by the Robinson-Patman Act, ${ }^{55}$ is concerned with discriminatory pricing and provides:

It shall be unlawful for any person engaged in commerce, in the course of such commerce, either directly or indirectly, to discriminate in price between different purchasers of commodities of like grade and quality . . . where the effect of such discrimination may be substantially to lessen competition or tend to create a monopoly in any line of commerce, or to injure, destroy, or prevent competition with any person who either grants or knowingly receives the benefit of such discrimination, or with customers of either of them .... .

The Supreme Court has held that a price difference is sufficient to qualify as price discrimination within the terms of this section. ${ }^{57}$ The statute does not ban all price differences and is qualified in a number of important ways. For example, the price difference must threaten

52. 15 U.S.C.A \& 2 (1997).

53. Id.

54. See 15 U.S.C. § $12(2000)$.

55. See 15 U.S.C. § 13(a) (2000).

56. Id.

57. Brooke Group Lid. v. Brown \& Williamson Tobacco Corp., 113 S.Ct. 2578, 2586 (U.S. 1993). 
to injure competition. ${ }^{58}$ This has been a problematic statutory provision from the standpoint of asserting consumer welfare as the central goal of antitrust. It has been described as a small business statute and as one that protects competitors and not competition. ${ }^{59}$ One important problem in American antitrust jurisprudence is whether Section 2 of the Sherman Act and Section 2(a) of the Clayton Act, as amended, involve similar standards of proof, or whether the latter involves a lesser standard such that findings of antitrust violation will become more readily available.

The American antitrust law applies internationally in certain circumstances pursuant to the terms of the Wilson Tariff Act, ${ }^{\infty}$ which provides:

Every combination, conspiracy, trust, agreement, or contract is declared to be contrary to public policy, illegal, and void when the same is made by or between two or more persons or corporations, either of whom, as agent or principal, is engaged in importing any article from any foreign country into the United States, and when such combination, conspiracy, trust, agreement, or contract is intended to operate in restraint of lawful trade, or free competition in lawful trade or commerce, or to increase the market price in any part of the United States of any article or articles imported or intended to be imported into the United States, or of any manufacture into which such imported article enters or is intended to enter. ${ }^{61}$

Apparently, few cases have interpreted the scope of this section. ${ }^{62}$ The leading case is Matsushita Electric Indus. Co., Ltd. v. Zenith Radio Corp. ${ }^{63}$ in which the lower court held that this statute was co-extensive with Section 1 of the Sherman Act. ${ }^{64}$ The court rejected the argument that the statute was

58. There are a number of relevant statutory defenses. One such defense is that the price discrimination is based on differences in costs "changing conditions affecting the market for or the marketability of the goods concerned," or conduct undertaken "in good faith to meet an equally low price of a competitor." Id. (citing 15 U.S.C. $\$ 13(\mathrm{~b})$ )).

59. See J.F. Feeser Inc. v. Serv-A-Portion Inc., 909 F.2d 1524-48 (1990). See also SPENCER WALLER, ANTITRUST LAW LIBRARY: INTERNATIONAL TRADE AND U.S. ANTITRUST LAW 2:28 (1996).

60. 15 U.S.C. $\$ 8 .(2000)$.

61. Id.

62. See WALLER, supra note 59, at 1:24-25.

63. Matsushita Electric Indus. Co. v. Zenith Radio Corp., 513 F. Supp. 1100, 1162-64 (E.D. Pa. 1981), aff'd in part and rev'd in part, 723 F.2d 238 (3d Cir. 1983), rev'd on other grounds, 475 U.S. 574 (1986).

64. Matsushita, 475 U.S. at 583. Section 1 of the Sherman Act provides: "Every contract, combination in the form of trust or otherwise, or conspiracy, in restraint of trade or commerce among the several States, or with foreign nations, is hereby declared to be illegal . . ." 15 U.S.C. \& 1 (2000). 
protectionist in nature and provided relief from foreign competition beyond the requirements of the other antitrust laws. The court also rejected the defendants' argument that the statute was more limited than the Sherman Act. ${ }^{65}$

Predatory and discriminatory pricing principles within American antitrust law have evolved during the past thirty years. Initially they shared the same producer-welfare orientation as current antidumping principles. Utah Pie Co. v. Continental Baking Co. ${ }^{66}$ reflects this orientation. It has since been described as one of the most anti-competitive antitrust decisions ever made within the United States. It was the first time the Supreme Court actually imposed and required a restraint of trade. ${ }^{67}$ The next section reviews the evolution of predatory and discriminatory pricing principles from Utah Pie through the Brooke Group case. The adoption of a consumer welfare orientation and market structure test is highlighted, as it identifies the kind of condition precedent that should be incorporated into NAFTA antidumping practices.

\section{A. Utah Pie and its Illusion of Price Discrimination}

Utah Pie Co. v. Continental Baking Co. involved allegations of discriminatory pricing between 1958 and 1961 by a local pie company in the Utah market against three national pie companies. The Court found that the major competitive weapon in the Utah market was price. ${ }^{68}$ The location of the Utah Pie plant gave it a natural advantage. It entered the market at a price below the national companies, sparking the price competition it later complained about. The remarkable feature of this case is that the complaint was brought even though Utah Pie was expanding its volume and maintaining its profitability during the period of the complaint. ${ }^{69}$ Notwithstanding Utah Pie's performance during the period, the jury awarded treble damages on the allegation of price discrimination, although allegations of conspiracy under the Sherman Act were dismissed. The court of appeals reversed, finding the evidence against the respondents insufficient to support a finding of probable injury to competition. ${ }^{70}$

The Supreme Court reversed and remanded, disagreeing with the court of appeal's view that there is no reasonable injury to competition possible as long as the volume of sales in a particular market is expanding and at least

65. See Matsushita, 513 F. Supp. at 1162-64. This finding was upheld by the court of appeals, but not referred to in the Supreme Court decision.

66. Utah Pie Co. v. Continental Baking Co., 386 U.S. 685 (1967).

67. See Ward S. Bowman, Restraint of Trade by the Supreme Court: The Utah Pie Case, 77 YALE L.J. 70, at 84-85 (1967-68),

68. Utah Pie, 386 U.S. at 690.

69. See id. at 691-92.

70. See id. at $686-87$. 
some of the competitors in the market continue to operate at a profit. ${ }^{71}$ The Supreme Court held that:

there was ample evidence to show that each of the respondents contributed to what proved to be a deteriorating price structure over the period covered by this suit and each of the respondents in the course of the ongoing price competition sold frozen pies in the Salt Lake market at prices lower than it sold pies of like grade and quality in other markets considerably closer to its plants. ${ }^{n}$

The Supreme Court also held that the Clayton $\mathrm{Act},{ }^{73}$ as amended by the Robinson-Patman Act, ${ }^{74}$ is not limited to those instances when price discriminators consistently undercut other competitors. The Court acknowledged that many "primary line cases" involve "blatant predatory price discriminations employed with the hope of immediate destruction of a particular competitor. ${ }^{75}$ The Court found that there was some evidence of predatory intent, although acknowledging that "[i]t might be argued that the respondents' conduct displayed only fierce competitive instincts." ${ }^{36}$ The Court further stated that:

There was also other evidence upon which the jury could rationally find the requisite injury to competition. The frozen pie market in Salt Lake City was highly competitive. At times Utah Pie was a leader in moving the general level of prices down, and at other times each of the respondents also bore responsibility for the downward pressure on the price structure. We believe that the Act reaches price discrimination that erodes competition as much as it does price discrimination that is intended to have immediate destructive impact. In this case, the evidence shows a drastically declining price structure which the jury could rationally attribute to continued or sporadic price discrimination. $^{\pi}$

71. Id. at 702. Of course, the other competitors of the national brands were not complainants. The only complainant, and the company to which damages would be paid, was the very company who had remained profitable through the period in question. See id.

72. Id. Utah Pie entered the market at a price of $\$ 4.15$ per dozen and was selling at a price at $\$ 2.75$ forty-four months later when the complaint was filed. $\mathbf{I d}$.

73. 15 U.S.C. $\$ 12(2000)$.

74. Id. § 13(a).

75. Utah Pie, 386 U.S. at 702.

76. Id. at 702, n. 14.

77. Id. at $702-03$. 
It has been argued that in Utah Pie the Supreme Court was showing a determination to change antitrust laws "designed to promote competition into laws that regulate or hamper the competitive process," and it used the Robinson-Patman Act "to strike directly at price competition itself." 78 The court of appeals finding of no probable effect on competition was overcome by the decline in the share of the market held by Utah Pie.

Thus, an adverse effect on a competitor, even on one in a quasi-monopoly position, whose sales and profits continue to expand, and whose only injury is the loss of market dominance as a result of price competition which he himself engenders, is enough for the Supreme Court. ${ }^{79}$

Bowman states "but that is not all," as Justice White "used the very evidence of competition which convinced the court of appeals that no violation existed to decide that there was an antitrust violation." 80

Outlawing price discrimination because it might transfer funds to kill or harass competitors deserves about as much support as outlawing income itself because it might be spent on burglars' tools. The pro-competitive aspects of price discrimination, in contrast, are manifest. ${ }^{81}$

The Utah Pie decision can be seen as supporting principles found within antidumping practice. A decreasing price structure alone can be found to be inimical to the competition within a particular market, without regard to a consideration of an appropriate pricing standard, whether based upon marginal costs, a fully-allocated cost standard or the antidumping standard covering all costs and allowing for a reasonable profit. One might infer that the antidumping standard was indeed used, due to the fact that liability was imposed, even though the Utah Pie company was enjoying an increase in profits. The erosion in price structure alone provides liability, and there is no apparent analysis of market structure included in the decision. Similar to antidumping practices, this case reflects a concern for producer welfare at the expense of consumer welfare.

78. Bowman, supra note 67 , at 70 . This article is the seminal economic analysis of the Utah Pie decision.

79. ld. at 73.

80. Id.

81. Id. at 83-84. 


\section{B. Areeda and Tumer: an Average Variable Cost-based Test of Preda- tion}

The Utah Pie decision, along with at least two other decisions in the $1960 \mathrm{~s},{ }^{82}$ reflect a high water mark in establishing a producer welfare orientation for antitrust law. The first major step in the evolution of predatory pricing theory to a consumer welfare orientation was the publication of Areeda and Turner's article, Predatory Pricing and Related Practices Under Section 2 of the Sherman Act, published in 1975..$^{83}$ This article became a focal point for academic scrutiny and had a significant influence on the courts thereafter.

Areeda and Turner start their analysis by indicating that the then existing treatment of predatory pricing in the courts and legal analysis suffered from two defects: (1) "failure to delineate clearly and correctly what practices should constitute the offense," and (2) "exaggerated fears that large firms will be inclined to engage in it." $\$ 4$ Vague formulations of the offense overlook the fact that predation "cannot exist unless there is a temporary sacrifice of net revenues in the expectation of greater future gains" 85 after rivals have been driven out of the market. Predatory pricing makes little economic sense unless the predator has: "(1) greater financial staying power than his rivals, and (2) a very substantial prospect that the losses incurred will be exceeded by the profits made after the predation has succeeded." 86 If monopoly power is achieved, the firm has, by definition, captured enough of the market to determine market price by varying its output and thus raising its price to supra-competitive levels. ${ }^{87}$ The second prerequisite is less likely to occur, unless "very high barriers to entry" exist. ${ }^{88}$ In many markets, entry barriers may be nonexistent or too low to prevent entry. Even though

82. See, e.g., United States v. Von's Grocery Co., 384 U.S. 270 (1966); Brown Shoe Co. v. United States, 370 U.S. 294 (1962).

83. Phillip Areeda and Donald F. Tumer, Predatory Pricing and Related Practices Under Section 2 of the Sherman Act, 88 HARV. L. REV. 697 (1975).

84. Id. at 698.

85. Id.

86. Id.

87. See id. at 702-03. Under circumstances of perfect competition, price will equal marginal cost, as the competitive firm has no power over market price. Any additional unit of output is equal to the price itself. This produces an efficient allocation of resources: the social optimum. However, when monopoly power exists, the selling of additional product will reduce price and so the monopolist faces a downward sloping demand curve. The incremental revenue to a monopolist is the lower price received for that unit as well as the lower revenue received from the sale of all its other production as a result of the lower price. Marginal revenue, therefore, is always below the price that generates it. The monopolist will only produce to the point where marginal cost equals marginal revenue and so marginal cost will be below the associated price. The monopolist's price is thus higher, and its output lower, than the social optimum; any higher output and lower price would be an improvement in resource use up to the point where, as in a competitive market, price equals marginal cost. See id.

88. Id. at 699. 
predatory pricing "seems highly unlikely does not necessarily mean that there should be no antitrust rules against it." 89

But it does suggest that extreme care be taken in formulating such rules, lest the threat of litigation, particularly by private parties, materially deter legitimate, competitive pricing. Courts in predatory pricing cases have generally turned to such empty formulae as "below cost" pricing, ruinous competition, or predatory intent in adjudicating liability. These standards provide little, if any, basis for analyzing the predatory pricing offense. ${ }^{90}$

Areeda and Turner submit that prices below marginal cost should be the point at which an inference of predatory intent can be made. By definition, a firm selling goods within this range is selling at least part of its output at an out-of-pocket loss. It could restrict either its output or cease production in the extreme case if the highest price the firm could obtain is below average variable cost at all levels of production. When above marginal cost, pricing should be tolerated because it leads to a proper resource allocation ${ }^{91}$ and is consistent with competition on the merits. When price is below marginal cost, the monopolist is incurring private losses and wasting social resources because marginal cost exceeds the value of what is produced. "[P]ricing below marginal cost greatly increases the possibility that rivalry will be extinguished or prevented for reasons unrelated to the efficiency of the monopolist ... [ [a]ccordingly, a monopolist pricing below marginal cost should be presumed to have engaged in a predatory or exclusionary practice. $" 92$

The final step in the Areeda and Turner predatory pricing analysis is the selection of average variable cost as a surrogate for marginal cost, due to the difficulty in measuring marginal cost. Few, if any, corporations actually track and engage in financial reporting based upon marginal cost. Areeda and Turner focus upon average variable costs to provide an inference that, when pricing falls below this level, predatory pricing intent exists. The

\section{Id.}

90. Id.

91. Areeda and Turner use the economic concept of perfect competition to establish this point. When this condition exists, marginal cost equals the market price. This solution in the perfectly competitive world also produces an efficient allocation of resources: market price reflects what consumers are willing to pay for the last unit of output; marginal cost reflects the full current cost of resources needed to produce it; a higher price would result in a reduction in output and thus deprive some buyers of a commodity for which they were willing to pay the cost of production.

See id. at 702.

92. Id. at 712. The only exception to this rule is in circumstances where price is below marginal cost but above average cost. It only occurs when demand exceeds what the firm can produce at minimum average cost. Equally efficient rivals will be making above-normal profits at this level because the firm in question is acting near capacity. 
importance of the test is that it abandons a fully allocated price standard on the basis that an economically rational agent can engage in pricing above marginal cost. It has proven to be a highly influential test, but note that the inference is based upon pricing practices alone without regard to the market structure that exists. For our purposes, antidumping and antitrust practices begin to diverge, but in a sense the difference between antidumping practices and the Areeda-Turner test is simply the price point at which the appropriate inference is drawn. There are other differences. The Areeda \& Turner test focuses exclusively upon the accused's pricing patterns and does not consider the financial circumstances of, or injury to, the complainant.

\section{Brooke Group Ltd. v. Brown \& Williamson Tobacco Corporation ${ }^{93}$}

The issues that the Supreme Court dealt with were: (1) the correct cost standard for determining predatory intent; (2) the role of a structural market analysis in respect of recoupment; and (3) the nature of the relationship

93. Brooke Group Ltd. v. Brown \& Williamson Tobacco Corp., 113 S.Ct. 2578 (U.S. 1993). The case involved cigarette manufacturing, a concentrated industry dominated by six firms. The plaintiff and applicant, Brooke Group, held a $2 \%$ market share while Brown \& Williamson held an $11.4 \%$ market share. Id. at 2582-83. In 1980, the plaintiff and applicant, the Brooke Group, developed a line of generic cigarettes offered at a list price roughly $30 \%$ lower than that of branded cigarettes. Id. By 1984, the generics had captured $4 \%$ of the market. Brown \& Williamson was hardest hit by the introduction of generics as its brands were costsensitive; $20 \%$ of the converts to Brooke Group generics came from Brown \& Williamson. Id. at 2583. Brown \& Willianson entered the generic segment at a lower net price. The Brooke Group responded precipitating a price war that they alleged ended with Brown \& Williamson selling its generics at a loss. See id. at 2584. The Brooke Group commenced the action alleging, inter alia, that volume rebates by Brown \& Williamson to wholesalers amounted to price discrimination that had a reasonable possibility of injuring competition contravening Section 2 of the Clayton Act as amended by the Robinson-Patman Act. The Brooke Group alleged further that the rebates were designed to force it to raise its prices thus restraining the growth of the generic segment and preserving Brown \& Williamson's supra-competitive profits on branded cigarettes. The jury found for the Brooke Group, but the verdict was overturned by the district court as a matter of law on three grounds: lack of injury to competition, lack of antitrust injury to Liggett, and lack of a causal link between the discriminatory rebates and Liggett's alleged injury. Id. at 2585. The trial court's "lack of injury to competition" finding was based on a conclusion that there was no tacit coordination of prices in the generic segment among the various manufacturers, and so Brown \& Williamson had no reasonable possibility of limiting the growth of the segment. Id. The court of appeals affirmed, holding that the dynamic of conscious parallelism among oligopolists could not produce competitive injury in a predatory pricing setting, which necessarily involves a price cut by one of the oligopolists. Id. "In the Court of Appeals' view, [t]o rely on the characteristics of an oligopoly to assure recoupment of losses from a predatory pricing scheme after one oligopolist has made a competitive move is . . economically irrational." Id. at 2586 . The syllabus was also used in describing the facts. See id. at 2580. 
between the Sherman $\mathrm{Act}^{94}$ and the Robinson-Patman $\mathrm{Act}^{95}$ regarding predatory and discriminatory pricing. ${ }^{\%}$

The Supreme Court held that price discrimination under the Clayton Act, as amended, "is merely a price difference," but "the statute as a practical matter could not, and does not, ban all price differences. . . ."97 Congress did not intend to outlaw price differences that result from or further the forces of competition. Thus, "the Robinson-Patman Act should be construed consistently with broader policies of the antitrust laws." 98 The Supreme Court then distinguished Utah Pie on the ground that "[a]s the law has been explored since Utah Pie, it has become evident that primary-line competitive injury under the Robinson-Patman Act is of the same general character as the injury inflicted by predatory pricing schemes actionable under $\S 2$ of the Sherman Act." ${ }^{\prime 99}$ The Court confirmed that there are differences between the two statutes, but that they share the same general characteristics:

For example, we interpret $\S 2$ of the Sherman Act to condemn predatory pricing when it poses 'a dangerous probability of actual monopolization,' . . . whereas the Robinson-Patman Act requires only that there be 'a reasonable possibility' of substantial injury to competition before its protections are triggered .... But whatever additional flexibility the Robinson-Patman Act standard may imply, the essence of the claim under either statute is the same: A business rival has priced its products in an unfair manner with an object to eliminate or retard competition and thereby gain and exercise control over prices in the relevant market.

Accordingly, whether the claim alleges predatory pricing under $\S 2$ of the Sherman Act or primary-line price discrimination under the Robinson-Patman Act, the two prerequisites to recovery remain the same. ${ }^{100}$

When predatory pricing or price discrimination is at issue, the first requirement is that "a plaintiff seeking to establish competitive injury resulting from a rival's low prices must prove that the prices complained of

94. 15 U.S.C.A $\$ 2$.

95. 15 U.S.C.A. $\$ 13(a)$.

96. The argument in respect of these issues was given added piquancy because Phillip Areeda and Robert Bork (the "titans of antitrust") argued the case for the plaintiff-appellant and defendant-respondent respectively, before the Supreme Court.

97. Brooke Group Ltd., 113 S.Ct. at 2586.

98. Id. (citing Great Atlantic \& Pacific Tea Co., Inc. v. FTC, 440 U.S. 69, 80, n. 13 (1979); Automatic Canteen Co. Of America v. FTC, 346 U.S. 61, 63, 74 (1953)).

99. $I d$. at 2587.

100. 1 . 
are below an appropriate measure of its rival's costs." 101 The Supreme Court declined to determine what constitutes an "appropriate measure" of costs because the parties agreed that the relevant measure of cost is average variable cost. ${ }^{102}$

The Supreme Court rejected the notion that "above-cost prices that are below general market levels or the costs of a firm's competitors inflict injury to competition cognizable under the antitrust laws. ${ }^{103}$ The protection of price competition was an important aspect of the decision.

Low prices benefit consumers regardless of how those prices are set, and so long as they are above predatory levels, they do not threaten competition .... We have adhered to this principle regardless of the type of antitrust claim involved. As a general rule, the exclusionary effect of prices above a relevant measure of cost either reflects the lower cost structure of the alleged predator, and so represents competition on the merits, or is beyond the practical ability of a judicial tribunal to control without courting intolerable risks of chilling legitimate price-cutting. To hold that the antitrust laws protect competitors from the loss of profits due to such price competition would, in effect, render illegal any decision by a firm to cut prices in order to increase market share. The antitrust laws require no such perverse result. ${ }^{104}$

With respect to Brown \& Williamson's pricing of generics evident in the case, the Supreme Court found that there was sufficient evidence "from which a reasonable jury could conclude that for a period of approximately 18 months, Brown \& Williamson's prices of its generic cigarettes were below its costs . . . and that this below-cost pricing imposed losses on [Brooke Group] that it was unwilling to sustain, given its corporate parent's effort to locate a buyer for the company." ${ }^{105}$ With the agreement between counsel in place accepting the average cost rule, Brown \& Williamson's prices were below average variable costs for a significant period of time, yet the court still did not impose liability, reflecting the importance the court attributed to the protection of price competition. The court also did not impose liability even though there was sufficient evidence that a reasonable jury "could conclude that Brown \& Williamson envisioned or intended this anti-

101. Id. (citing Cargill, Inc. v. Monfort of Colorado, Inc., 479 U.S. 104 (1986); and Matsushita Electric Industrial Co., Ltd. v. Zenith Radio Corp., 475 U.S. 574 (1986)).

102. ld. at n.1. It is not surprising that Areeda and Bork would agree to this standard. Areeda co-authored the average variable cost standard, while Bork, by inclination and as counsel for the defendant, would want the most permissive cost-based test possible.

103. Id. at 2588 (citing Atlantic Richfield Co. v. USA Petroleum Co., 495 U.S. 328,340 (1990)).

104. Id. (quoting Cargill, 479 U.S. at 116)(citations ommitted).

105. Id. at 2592. 
competitive course of events", and thus subjective predatory intent could be established. ${ }^{106}$

The reason why the below-cost pricing in this case was not actionable is due to Brown \& Williamson's failure to meet the second requirement, which is "a demonstration that the competitor had a reasonable prospect, or, under $\S 2$ of the Sherman Act, a dangerous probability, of recouping its investment in below-cost prices." 107 After having relied upon below-cost pricing, Areeda appears to have attempted to minimize the role of the recoupment approach by stating that "recoupment is simply the payoff for below-cost pricing." 108 His position in this regard is consistent with the absence of such a requirement in his formulation of the average variable cost test. The Supreme Court held:

Recoupment is the ultimate object of an unlawful predatory pricing scheme; it is the means by which a predator profits from predation. Without it, predatory pricing produces lower aggregate prices in the market, and consumer welfare is enhanced. Although unsuccessful predatory pricing may encourage some inefficient substitution toward the product being sold at less than its cost, unsuccessful predation is in general a boon to consumers. ${ }^{109}$

Here, the Court has indicated that inefficient substitution toward the product being sold at less than cost is not actionable. As a result of the pricing practices evident in the case, the result holds even if the pricing involved is below average variable cost for a period of twelve to eighteen months.

The Supreme Court gave pre-eminent importance to price competition, holding that the painful losses below-cost pricing may impose on target

106. Elzinga and Mills, Trumping the Areeda-Turner Test: The Recoupment Standard in Brooke Group, 62 ANTIrRUST L.J. 559, 579-91 (1994):

The third is that the Court now places so much confidence in a recoupment approach to predation that it will ignore the kind of evidence that, in Utah Pie, figured prominently: documents about the defendant's intentions .... .

There were so many such documents that the district court distinguished Brooke Group from other predation cases by claiming that the number of Brown \& Williamson documents indicating anticompetitive intent are more voluminous and detailed than any other reported case.

Id.

107. Brooke Group, 113 S.Ct., at 2588 (citing Matsushita Electric Industrial Co., Ltd. v. Zenith Radio Corp., 475 U.S. 574 (1986) and Cargill, Inc. v. Monfort of Colorado, Inc., 479 U.S. 104 (1986)).

108. Elzinga and Mills, supra note 107, at 583 (quoting from Brief of Appellant at 4, Brooke Group v. Brown \& Williamson Tobacco Corp., 113 S.Ct. 2578 (U.S. 1992)(written by Phillip Areeda)).

109. Brooke Group. 113 S.Ct. at 2588. 
companies are irrelevant to the antitrust laws if competition is not injured, quoting the principle expressed in an earlier case that the antitrust laws were passed for "the protection of competition, not competitors." "110 The importance of price competition is reflected in the statement that "[e]ven an act of pure malice by one business competitor against another does not, without more, state a claim under the federal antitrust laws; those laws do not create a federal law of unfair competition or 'purport to afford remedies for all torts committed by or against persons engaged in interstate commerce'. ${ }^{n 11}$ The required evidence regarding market structure also reflects that recoupment is possible. As a threshold matter, below cost pricing must be capable of driving competitors from the market or, as alleged in Brooke Group, causing them to raise their prices to supra-competitive levels within a disciplined oligopoly. This requires a market analysis of the relative financial strength of the predator and its intended victim and a consideration as to whether the target will likely succumb given the aggregate losses caused by the below-cost pricing. ${ }^{112}$ If the below-cost pricing might produce its intended effect on the target, there is still the further question whether it would likely injure competition in the relevant market. The plaintiff must demonstrate the likelihood that the alleged predatory scheme would cause a rise in prices above a competitive level that would be sufficient to compensate for the amounts expended on the predation, including the time value of the money invested in it. The Supreme Court held that, "[i]n order to recoup their losses, [predators] must obtain enough market power to set higher than competitive prices, and then must sustain those prices long enough to earn in excess profits what they earlier gave up in below-cost prices." ${ }^{113}$ The finding of recoupment requires a structural analysis:

Evidence of below-cost pricing is not alone sufficient to permit an inference of probable recoupment and injury to competition. Determining whether recoupment of predatory losses is likely requires an estimate of the cost of the alleged predation and a close analysis of both the scheme alleged by the plaintiff and the structure and conditions of the relevant market .... If market circumstances or deficiencies in proof would bar a reasonable jury from finding that the scheme alleged would likely result in sustained supracompetitive pricing, the plaintiff's case has failed. In certain

110. Id. at 2588-89 (quoting Brown Shoe Co. v. United States, 370 U.S. 294, 320 (1962)). It is interesting to note that the court relies upon the first branch of the Brown Shoe quote without rationalizing the second branch '[b]ut we cannot fail to recognize Congress' desire to promote competition through the protection of viable, small, locally-owned businesses." Id.

111. Id. at 2589 (quoting Hunt v. Crumboch, 325 U.S. 821, 826 (1945)).

112. Id. at 2589 (citing Matsushita Electric Industrial Co., Ltd. v. Zenith Radio Corp., 475 U.S. 574 (1986)).

113. Id. 
situations - for example, where the market is highly diffuse and competitive, or where new entry is easy, or the defendant lacks adequate excess capacity to absorb the market shares of his rivals and cannot quickly create or purchase new capacity - summary disposition of the case is appropriate. $^{114}$

The Court notes that the two prerequisites, below cost pricing and recoupment, "are not easy to establish, but they are not artificial obstacles to recovery; rather, they are essential components for real market injury." 115 The Court refers to its dictum in Matsushita that "predatory pricing schemes are rarely tried, and even more rarely successful" and notes that "the costs of an erroneous finding of liabilities are high." 116 Price competition is the same mechanism by which a firm engages in predatory pricing or stimulates competition. As "cutting prices in order to increase business often is the very essence of competition ... mistaken inferences . . . are especially costly, because they chill the very conduct that the antitrust laws are designed to protect." 117 The Court further notes, "[i]t would be ironic indeed if the standards for predatory pricing liability were so low that antitrust suits themselves became a tool for keeping prices high. ${ }^{n 18}$

The Supreme Court affirmed the decision of the Court of Appeals, upholding the dismissal of the case. ${ }^{119}$ The Brooke Group failed to demonstrate competitive injury because it could not show that "Brown \& Williamson had a reasonable prospect of recovering its losses from belowcost pricing through slowing the growth of generics." 120 No evidence indicated that Brown \& Williamson "was likely to obtain the power to raise the prices for generic cigarettes above a competitive level. ${ }^{\text {121 }}$

The implications of this case are many. Elzinga and Mills argue that the cost-based tests have now receded in importance, and that the structural test is the dominant or threshold requirement. ${ }^{122}$ This analysis appears to be correct. The importance of the structural test is evident in the fact that no finding of predatory or discriminatory pricing existed even though Brown \& Williamson had priced its goods below average variable costs and that evidence of subjective predatory intent was replete in Brown \& Williamson's records. The cost-based rules generally allowed drawing an inference of predatory intent when pricing was evident in this range. After Brooke

114. Id. (citing Cargill, Inc. v. Monfort of Colorado, Inc., 479 U.S. 104 (1986)).

115. Id.

116. Id. (quoting Matsushita, 475 U.S. at 589).

117. Id. at 2589-90 (quoting Cargill, 479 U.S. at 122).

118. Id. at 2590.

119. Id. at 2578 .

120. Id. at 2592 .

121. Id.

122. See Elzinga and Mills, supra note 106, at 578-80, 582-84. 
Group, such inferences are not permissible without the appropriate finding of a market structure allowing recoupment. The interests of consumers are now of such pre-eminent importance that they are entitled to the benefit of low pricing introduced with the subjective intent of driving competitors from the market, as long as the market structure indicates that the attempt to monopolize has little chance to succeed.

The case is also notable due to Posner's analysis that predatory pricing includes two different forms of inefficient substitution; toward the product during the period of low pricing, and away from the product during the period of subsequent monopolization. ${ }^{123}$ Cost-based rules permitting a finding of liability without a structural market analysis would target either form of inefficient substitution. The Supreme Court has expressly held that the first kind of inefficient substitution cannot sustain an antitrust cause of action.

The Brooke Group determination marks the evolution of antitrust predatory pricing principles from the shared perspective of producer welfare to a consumer welfare orientation. In addition, an analysis of pricing practices alone cannot provide the inference of anti-competitive conduct. A detailed structural analysis must be undertaken, and a market structure found, that allows an inference that recoupment is possible. If not, consumers benefit from lower prices notwithstanding the possibility of anti-competitive intent providing the motivation for price competition.

\section{A MARKET STRUCTURE TEST FOR NAFTA/FTAA ANTIDUMPING PRACTICES}

There are a number of profound differences between antidumping and antitrust principles with respect to what constitutes actionable pricing. A geographical difference in pricing is sufficient for antidumping practices, even if the prices charged are above marginal price and at levels marking an unacceptably low de minimus threshold for the imposition of duties. No analysis of price in relation to cost is necessary, unless a constructed cost analysis is undertaken which is based upon a fully allocated cost standard versus the marginal cost standard proposed by the Areeda-Turner test. No consideration is given to the fact that if the prices in the export-home market truly are higher, an opportunity should exist for market entry. If antidumping duties are imposed when such an opportunity exists, they achieve a suppression of price competition in the complainant-import market and dampen the incentive placed upon domestic producers to aggressively seek an expansion of sales in at least the export-home market.

Actionable pricing pursuant to antitrust standards has evolved from a simple pricing trigger point provided by the Areeda-Turner test (below average variable cost, a standard intended as a surrogate for marginal cost) 
to an assessment of market structure. Although not yet endorsed by the U.S. Supreme Court, the marginal cost standard highlights the unfairness of the antidumping standard requiring prices above a fully-allocated cost standard, as antidumping duties can be imposed even when the respondent company has acted rationally in its pricing policy. In the antitrust context, the addition of a market structure analysis in the form of a recoupment test results in pricing below marginal cost being actionable only in rare circumstances where a market structure exists which allows recoupment of profits lost during the predatory campaign. Antitrust protects consumer welfare by promoting price competition even if it is below cost, in certain circumstances.

Antidumping law has no concept of a recoupment test and, indeed, no market structure analysis is undertaken, except in the context of the determination of injury. The problem is that the threshold of injury, or the threat thereof, is relatively low and concentrates solely upon the economic condition of the complainants in the import market. It tends to ignore the conditions of entry in the exporter's home market, which would allow a determination whether there is some structural impediment or whether a competitive opportunity exists which the complainants have failed to exploit. Similarly, there is no analysis as to whether there is any danger of recoupment through an escalation of prices in the complainant-import market, assuming for the moment that the low pricing did signify a predatory campaign intended to drive the complainant-import market producers out of business.

The contrast between antidumping practices making actionable pricing above a fully-allocated cost standard and antitrust principles, in which pricing below marginal cost is often protected, highlights the important difference in orientation between the two systems of law. As indicated above, antidumping law protects producer welfare while antitrust law protects consumer welfare. The question arises whether this difference in orientation is justified in the circumstances of a regional free trade agreement intended to remove most, if not all, barriers to trade across a large variety of market segments. Under the terms of a free trade agreement where barriers have been dismantled in a particular sector, there appears to be no justification for maintaining antidumping practices.

Canada has already established the precedent for the elimination of antidumping practices in the Canada-Chile Free Trade Agreement and should follow it in future negotiations. In the alternative to complete elimination of the mechanism, a market structure test should be established requiring the complainant to identify particular market impediments that insulate the home market, thereby allowing a higher price to be maintained. Antidumping duties should be imposed only if the complainant can establish that a particular public or private impediment exists which allows the exporter to discriminate between its home market and the complainant-import market. 
The impediment cannot be one based upon efficiency, and causation must be established.

\section{A. Actionable Private Practices in the Context of Canadian-American Trade}

Apart from a government regulatory restriction, the question arises.as to what private practices might be cited by a complainant as a market impediment. In the context of bilateral trade between the United States and Canada, a complainant might utilize its own competition law in determining whether anti-competitive conduct has resulted in the erection of an actionable market impediment. Both Canada and the United States have mature competition law regimes and regulatory infrastructures at an advanced stage of development, when compared to the significant number of new competition codes that have been adopted by developing and emerging economies throughout the world.

To illustrate the manner in which the mechanism could work between fully-developed economies, if the United States was seeking to impose antidumping duties on Canadian products, the American administrative tribunal would apply domestic competition law to the market structure of the industry in question in the export-home market to see if American or other foreign goods are being excluded by anti-competitive conduct. If such conduct is occurring, the United States would be permitted to impose antidumping duties determined according to existing practices. In the absence of such conduct, no antidumping duties could be imposed.

The competition law of the complainant's jurisdiction has been chosen because the duties are only being imposed in that market. The test is intended to be a filter making antidumping duties hard to obtain, and the administrative tribunals asked to make such a finding will be most familiar with domestic legal standards. If the administrative tribunal asked to make the determination is the competition law authority, the interpretation of the law should be consistent with other determinations made in the domestic context. This would prevent selective interpretation of competition law in a manner freed from concern for the orderly development of competition law within the domestic context.

The Brooke Group ${ }^{124}$ case established that the same principles underlie predatory pricing or discriminatory pricing allegations under either the Sherman Act ${ }^{125}$ or the Robinson Patman Act. ${ }^{126}$ If the market structure test was to be adopted in the circumstances of NAFTA, ${ }^{127}$ complainants within the United States would be required to meet the Brooke Group thresholds,

124. Brooke Group v. Brown \& Williamson Tobacco Corp., 113 S.Ct. 257 (U.S. 1993).

125. 15 U.S.C.A \$ 2 (1997).

126. 15 U.S.C.A \& 13 (1997).

127. See NAFTA, supra note 7. 
involving: (1) pricing below a reasonable standard and (2) a market structure exists that permits recoupment. The pricing standard appears to be the average variable cost standard surrogate for marginal costs established by the Areeda-Turner test, although the Supreme Court has not determined that this is indeed the correct standard. The acceptance of an average variable cost standard would have the benefit of substituting a rational pricing standard for the fully-allocated cost standard accepted in antidumping practices. ${ }^{128}$

We readily admit that the imposition of such a market structure test would result in a severe curtailment of antidumping complaints or, even more happily, the effective elimination of antidumping practices. In fact, this is the objective of the imposition of such a requirement. The difficulty of succeeding in circumstances of international price discrimination allegations should such a market structure test be imposed is underscored by the Supreme Court decision in Zenith v. Matsushita. ${ }^{129}$ This case involved allegations that twenty-one Japanese corporations dumped televisions into the American market as part of a conspiracy to drive American firms from the market, while maintaining artificially high prices for television sets sold in Japan. ${ }^{130}$ The Supreme Court dismissed predatory pricing allegations made pursuant to the Sherman Act ${ }^{131}$ and the Robinson Patman Act ${ }^{132}$ on the basis that predatory pricing conspiracies by their very nature are speculative, and there must exist the possibility of recoupment of lost profits after the American competitors were driven from the market. ${ }^{133}$ The Court found that the proffered objective of the alleged twenty-year-old conspiracy was yet far distant. ${ }^{134}$ The Court also found that the casual connection between higher pricing decisions in one market and lower pricing decisions in a different more competitive market is questionable. ${ }^{135}$

Nor does the possibility that petitioners have obtained supracompetitive profits in the Japanese market change this calculation. Whether or not petitioners have the means to sustain substantial losses in this country over a long period of time, they have no motive to sustain such losses absent some strong likelihood that the alleged conspiracy in this country will eventually pay off. The courts below found no evidence of any such success, and-as indicated above-the facts actually are to the contrary: RCA and

128. Of course, trade negotiators might be forgiven for maintaining the fully-allocated cost standard as a quid pro quo for imposing the second or market structure threshold of the Brooke Group test.

129. Matsushita Electric Industrial Co., Ltd. v. Zenith Radio Corp., 475 U.S. 574 (1986).

130. See id. at 577-8.

131. 15 U.S.C. art. 2.

132. 15 U.S.C. art. 13(a).

133. Matsushita, 475 U.S. at 588-93.

134. Id. at 591 .

135. Id. at 593. 
Zenith . . . continue to hold the largest share of the American retail market in color televisions sets. More important, there is nothing to suggest any relationship between petitioners' profits in Japan and the amount petitioners could expect to gain from a conspiracy to monopolize the American market. In the absence of any such evidence, the possible existence of supra-competitive profits in Japan simply cannot overcome the economic obstacles to the ultimate success of this alleged predatory conspiracy. ${ }^{136}$

The point is that there must be a market structure permitting recoupment of profits lost during the period of predatory conduct in the U.S. market. If no such market structure exists, the fact of profits in a foreign jurisdiction is irrelevant, and allegations of cross-subsidization are not actionable. Price competition should be protected.

The Zenith v. Matsushita ${ }^{137}$ case provides another bridge between competition law and antidumping practices. The American complainants included antidumping allegations in the complaint pursuant to the 1916 Antidumping Act. ${ }^{138}$ This statute creates a private cause of action and prohibits an importer from selling substantially below the actual market value or wholesale price prevailing in either the country of production or another foreign market when the dumping is undertaken with the intent of injuring a U.S. industry. ${ }^{139}$ The statute penalizes dumping undertaken with the specific intent of "destroying or injuring an industry in the United States, or of preventing the establishment of an industry in the United States, or of restraining or monopolizing any part of trade and commerce in such articles in the United States." 140 The district court granted summary judgment and dismissed both the competition law and antidumping allegations. The Third Circuit Court of Appeals heard an appeal concerning the antidumping allegations and held that there was sufficient direct and circumstantial evidence of, among other things: (1) high barriers of entry to the Japanese market; (2) the Japanese manufacturers "created higher plant capacities than could reasonably be absorbed by the Japanese home market, thereby creating an incentive to dispose of the excess capacity in markets outside Japan"; and (3) "an agreement to stabilize Japanese home market prices to realize the profits needed to support sales at low prices in the United States" which

136. Id. at 593.

137. Id.

138. 15 U.S.C. $\$ 72$ (1994). In WTO complaints commenced by the European Community and Japan, the 1916 Antidumping Act was found inconsistent with United States' obligations under the WTO Agreements. See Appellate Body Report, United States-Antidumping Act of 1916, WT/DS136/AB/R;WT/DS162/AB/R, AB-2000-5, AB-2000-6, available at http:/www.wto.org/english/tratop_e/dispu_e/distab_e.html.

139. Rethinking the 1916 Antidumping Act, 110 HARv. L. REV. 1555 (1997).

140. 15 U.S.C. \$ 72; see also Rethinking the 1916 Antidumping Act, supra note 140 , at 1557 (quoting 15 U.S.C. \& 72). 
produced losses often as high as twenty-five percent on sales. ${ }^{141}$ The Supreme Court found that there was no motive to continue the predatory campaign in the United States and refused to deal with the antidumping issues. ${ }^{142}$ On remand regarding the antitrust issues, the court of appeals dismissed the entire case, holding that it was bound to do so by the Supreme Court's finding that the Japanese defendants had no motive to sustain substantial losses over a sustained period of time. ${ }^{143}$

It might be suggested that if a market structure test is imposed with respect to antidumping practices, any complainant should proceed under the competition laws and ignore the antidumping practices entirely. One of the most important aspects of American antitrust law is the entitlement to treble damages available through the private right of action by those injured by the improper conduct. ${ }^{144}$ If a market structure can be proven such that the court accepts that recoupment is possible, there is an incentive to proceed under the antitrust statutes, at least in the United States, to take advantage of the treble damages provision. Diverting antidumping disputes to determination under antitrust law is an acceptable result because it achieves the effective elimination of antidumping practices in favor of a competition law mechanism.

\section{B. Actionable Private Practices in the Context of Developing Economies with New Competition Codes/authorities}

The problem with using the provisions of domestic competition law to establish whether an actionable private practice exists is that those trade agreements, such as the FTAA ${ }^{145}$ initiative, include developing economies in Central and South America as well as the Caribbean. Some of these potential free trade partners have newly enacted competition codes and institutions that do not enjoy the traditions, policy infrastructures, and resources that are evident in Canada and the United States. Professor William Kovacic reports that more than forty emerging economies have enacted new antitrust laws since 1975, and as many as twenty more are likely to do so within the next

141. In Re Japanese Electronic Products Antitrust Litigation, Zenith Radio Corp. and National Union Electric Corp., 807 F.2d 44, 47 (3d Cir. 1986).

142. Matsushita, 475 U.S. 574 n.3.

143. In re Japanese Electronic Products, 807 F.2d at 47.

144. Section 4 of the Clayton Act provides:

Except as provided in subsection (b) of this section, any person who shall be injured in his business or property by reason of anything forbidden in the antitrust laws may sue therefor in any district court of the United States in the district in which the defendant resides or is found or has an agent, without respect to the amount in controversy, and shall recover threefold the damages by him sustained, and the cost of suit, including a reasonable attorney's fee ....

15 U.S.C. \&15(a) (2000).

145. FTAA, supra note 3. 
decade ${ }^{146}$ He points to a number of concerns with the development of these new institutions, including that they are often given a number of functions, ${ }^{147}$ they often have political and social objectives imposed upon them with economic efficiency playing a role of lesser importance, ${ }^{148}$ and they are often poorly funded and staffed. ${ }^{149} \mathrm{He}$ also indicates that the new competition law institutions exist on fragile political foundations and often "begin operating without the political ties and power base that [their] adversaries inside and outside the government will enjoy." "Is0 In addition, there is a relative absence of competition policy expertise and experience which can result in a relatively difficult environment for the requisite traditions to take root. ${ }^{151}$ The situation is further complicated by what Kovacic terms "dysfunctional courts" and because "[f]ew judges have even a rudimentary understanding of market processes, let alone comprehension of the basic rationale for and elements of an antitrust system."152 Why then are there so many new competition laws being introduced? Kovacic indicates that one of the primary motivating factors is Western donors and institutions, such as the World Bank and the International Monetary Fund, tying the provision of aid in part to the development of competition law institutions. He indicates that these well-meaning donors may not have the long-term commitment to funding these institutions. ${ }^{153}$

Kovacic recommends a gradualist approach to the implementation of competition laws and institutions instead of a "big bang" introduction of the entire panoply of antitrust rules and remedies. ${ }^{154}$ We suggest that the objective of introducing competition law traditions might be facilitated by including a competition law-based market structure test directly into the free trade agreement itself. As reviewed above, antidumping practices are based upon detailed rules contained in a fully developed code within the WTO Agreements. It should be possible to modify the code in the context of the free trade agreement. The inclusion of the rules in the supra-national agreement would provide guidance to the newly established competition law and trade authorities in the developing nations. It might provide them with valuable experience in dealing with the competition law concepts that are

146. William E. Kovacic, Competition Policy for Transition Economies 1 (May 14, 1999)(unpublished manuscript on file with authors).

147. On occasion, they include antitrust, consumer protection, and trade law responsibilities. In Peru, the administrative tribunal, Indecopi, has responsibility for antitrust, bankruptcy, consumer protection, intellectual property, and trade policy functions. See id. at 16.

148. See id. at 13-15.

149. See id. at 16-17.

150. Id. at 19.

151. Id. at 19-20.

152. Id. at 20.

153. William E. Kovacic, Getting Started: Creating New Competition Policy Institutions in Transition Economies, 23 BROOK. J. INT'L L. 403, at 407, 422, and 428 (1997).

154. Kovacic, supra note 146, at 28. 
established thereby, such as the importance of consumer welfare as a competition law objective. The mechanism would also benefit from the analysis of the mechanism available through competition law authorities in Canada and the United States, as well as the scrutiny of the mechanism by the well-established academic and professional association commentators who will subject it to extensive critical analysis. Each decision would be subject to criticism, especially in the early stages. Contacts will also be fostered between such competition law institutions and those in the developing nations and transitional economies. As Kovacic indicated, this is an important element in establishing competition law traditions.

The development of competition law traditions in the developing nations that have only recently adopted them or otherwise do not have much experience with them will also be fostered by the institutions that would be established in support of the free trade agreement. At the very least, the secretariats that have been established in the jurisdiction of each free trade partner, although relatively meager, would help coordinate the resources provided in support of the mechanism. The decisions emanating from the various jurisdictions, especially from Canada and the United States, would also provide an impetus for uniform interpretation of the market structure test principles included in the free trade agreement. This uniformity of interpretation would be promoted even if the decisions from the various jurisdictions did not have the binding authority of legal precedents. ${ }^{155} \mathrm{~A}$ more important authority for developing uniform interpretation would be the oversight of domestic decisions through the establishment of a bi-national or multi-national panel mechanism and an Extraordinary Challenge Committee, each having become commonplace in the CUSFTA and the NAFTA. The bi-national panel process, although exhibiting some weaknesses, receives credit for forcing domestic administrative tribunals to document and clarify their reasoning in a more rigorous fashion than had been evident before such international oversight was established. One of the weaknesses of the NAFTA bi-national panel mechanism is the shackling of the panels to a judicial standard of review. The bi-national panel process, in the context of a market structure impediment, would be improved if the panels were permitted to undertake de novo review of the final decisions of domestic administrative tribunals.

The question arises as to what principles should be included in the free trade agreement regarding a market structure mechanism. Antidumping involves allegations of predatory pricing or regional price discrimination. It is submitted that the appropriate principles would be those established by the Brooke Group precedent because they were developed in the context of such allegations. The principles include, that the complainant must demonstrate:

155. Chapter 19 of NAFTA specifically provides that the decisions of the bi-national panels do not have binding authority as precedents. Notwithstanding this, the decisions do appear to have persuasive power. See NAFTA, supra note 7, ch. 19. 
(1) pricing below a reasonable standard and (2) a market structure exists that permits recoupment. ${ }^{156}$ The appropriate pricing standard should be the average variable cost standard surrogate for marginal costs, established by the Areeda-Turner test. This would have the benefit of substituting a more rational pricing standard for the fully-allocated cost standard accepted in antidumping practices. However, the objective is to implement a market structure test that will make the imposition of antidumping duties difficult if not impossible to achieve. It would be an acceptable compromise if the price is the continuance of a fully-allocated cost standard.

The benefit of including the Brooke Group standard is that it firmly establishes consumer welfare as the appropriate objective for the mechanism, and it sets a high threshold. Basing the mechanism on American law should make it more palatable to American trade negotiators and Congress. The chance to establish a competition law precedent in the free trade agreement and promote the development of competition law traditions within developing nations without such traditions should also be of interest to the United States. This is not to underestimate the difficulty, if not impossibility, of substantially reforming antidumping practices through the imposition of a market structure test. If protectionism is on the rise in the United States, and since Canada has begun negotiations with Costa Rica and eventually other Central and South American nations in a quasi-FTAA, why not experiment with such a reform? Of course, it is unknown at this point whether President-elect George W. Bush will have greater success obtaining fast-track authority from Congress to recommence the full FTAA negotiations.

\section{Actionable Public Provisions Subject to Review}

The logic of the argument set forth in the Standing Committee Report would suggest that the complainant should be required to show that a particular public practice acts as a barrier to entry and allows the respondent to undertake international price discrimination. If the particular public practice in question does not impede market access, then the case to impose duties appears to be lacking because higher prices in the export-home market should attract market entry. A market impediment could be the continuing existence of a tariff or some other regulatory restriction which insulates the domestic market. If the only restriction between the markets is a tariff, the antidumping duty that could be imposed should be limited to the amount of the tariff. For instance, if a tariff of $2.5 \%$ ad valorem exists, an antidumping duty might be limited to the same figure. It would seem somewhat absurd if a market impediment could only impose a $2.5 \%$ difference in price, as this could result in antidumping duties in double digit figures. In our view, if antidumping practices are to be maintained with the addition of a market structure test, blatant impediments such as the continuing existence of a 
tariff, should be sufficient to trigger the application of antidumping duties, assuming that the other requirements can be met.

The more difficult issue is what public practices or non-tariff barriers should be sufficient to justify the imposition of antidumping duties, which may have a much more subtle effect than a blatant tariff barrier. A mere difference in regulatory environments should not be sufficient. Labor laws, environmental laws, or the income tax structure might be different, but mere differences in the regulatory environment should not be actionable when they are general in nature, such that all firms are subject to compliance on a national treatment basis. These differences may not give rise to an ability to discriminate between markets in a manner that permits supra-competitive profits to be realized. In the case of more subtle market impediments, the complainant should have the obligation to prove that the particular public practice complained of permits the respondent to discriminate between the home or export market and the complainant-import market and realize supracompetitive profits in the export-home market. This requires that the complainant show that the public practice has acted as an "artificial" barrier to entry, preventing the respondent from selling into the export-home market.

The concept of a "barrier to entry" introduces a potentially difficult analytical issue to the market structure test. ${ }^{157}$ Professor Bork rejects a large number of conditions which some argue constitute barriers to entry and which he views as advantages obtained as a result of greater efficiency. ${ }^{158}$ Professors Bork and Posner appear to agree as to what might constitute an artificial barrier, with Bork suggesting that they are barriers not based upon efficiency which prevent market entry or "the growth of smaller firms already within the industry from operating to erode market positions not based on efficiency." ${ }^{159}$ Posner extends this concept by stating that an artificial barrier "must be something that makes the small firm's marginal costs as high as the monopoly price charged by the leading firms so that the small firm cannot make money by shading that price." 160 Both appear to

157. There are at least two definitions of a barrier to entry. The "Bainian" definition states that entry barriers measure the extent to which, in the long run, established firms can elevate their selling prices above the minimal average costs of production and distribution without inducing potential entrants to enter the industry. See Herbert HovenKaMP, FEDERAL ANTTTRUST POLICY, THE LAW OF COMPETTTION AND ITS PRACTICE 39 (1994). The "Stiglerian" definition provides that "entry barriers are costs that a prospective entrant must incur at or after entry, that those already in the market did not have to incur when they entered." Id. at 39-40.

158. These include economies of scale, physical product differentiation, advertising and promotion, capital requirements, dealerships, leases and deferred rebates. See ROBERT H. BORK, THE ANTITRUST PARADOX, A POLICY AT WAR WITH ITSELF 310-29 (1978).

159. Id. at 311. Posner accepts this definition: "a barrier to entry is a condition that imposes higher long-run costs of production on a new entrant than are borne by the firms already in the market." RICHARD A. POSNER, ANTITRUST LAW, AN ECONOMICPERSPECTIVE 59 (1976)(citing George J. Stigler, Barriers to Entry, Economies of Scale, and Firm Size, in ORGANIZATION OF INDUSTRY 67 (1968)).

160. RiCHARD A. POSNER, AN ECONOMIC PERSPECTIVE 92 (1992). 
suggest that an artificial barrier to entry is in reality an exclusionary practice that would otherwise be actionable and so the concept of an artificial barrier adds little if anything to antitrust analysis. By concentrating upon exclusionary and collusive practices, artificial barriers are sorted out from efficient barriers, ${ }^{161}$ and this is why we based the antidumping market structure test on the Brooke Group standard.

While the concept of a barrier to entry is somewhat difficult in the context of a private practice, it is generally recognized that public practices can represent an important source of barriers to entry. Hovenkamp states that "[v]irtually all sides agree that government regulation, licensing and entry restrictions collectively create among the greatest and most effective entry barriers." 162 Bork argues that "[p]redation by abuse of governmental procedures, including administrative and judicial processes, presents an increasingly dangerous threat to competition." 163

In the early years of antitrust policy there were fewer opportunities for monopolization through misuse of government because governmental regulation was not so pervasive as it is today. The last several decades have witnessed an enormous proliferation of regulatory and licensing authorities at every level of government, federal, state, and local. In order to enter the market and vie for consumers' favor, businesses of all types must gain various types of approval from governmental agencies, departments, and officials. Licensing authorities, planning boards, zoning commissions, health departments, building inspectors, public utilities commissions, and many other bodies and officials control and qualify the would-be competitor's access to the marketplace. . . . The modern profusion of such governmental authorities offers almost limitless possibilities for abuse. ${ }^{164}$

While artificial barriers to entry arising from private practices are considered rare, restrictions upon market access imposed by government action can be effective barriers, particularly if government restrictions are

161. See id. "In short, it takes a good deal of strained and ad hoc argumentation to explain persistent monopoly or concentration without assuming unlawful exclusionary practices, lawful patent protection, economies of scale, superior management, competitive pricing, or other factors that would not normally justify dissolution proceedings." Id. at 93. See also BORK, supra note 158. "An artificial barrier to entry is, of course, an exclusionary practice .... Every barrier will be either a form of efficiency deliberately created or an instance of deliberate predation. There is no 'intermediate case' of non-efficient and unintended exclusion. Failure to bear that in mind leads to serious policy mistakes."

162. HOVENKAMP, supra note 157, at 473.

163. BORK, supra note 158 , at 347 .

164. Id. 
coordinated with private practices through administrative guidance. Such barriers to trade represent a difficult challenge for competition law which generally does not extend to public practices as a result of "state action" doctrines which are reportedly found in most if not all competition law regimes. ${ }^{165}$

Before antidumping duties can be imposed, the complainant should be required to show that a public practice is a barrier to entry and a proximate cause of price discrimination between the export-home market and the complainant-import market. The price discrimination in question must produce greater profit margins in the export-home market such that the price discrimination is not simply a reflection of a difference in cost structure between the two jurisdictions. ${ }^{160}$ The evidence that a public practice represents a barrier to entry could best be provided by an attempt to actually sell into the export-home market by the complainant itself, but the complainant should have the opportunity to establish that other international competitors in the particular market segment have similarly been unable to sell into the export-home market.

\section{The Appropriate Remedy}

Thus far, the market structure test has been discussed in the context of a remedy involving the imposition of antidumping duties if an actionable private or public practice is identified and the traditional antidumping requirements have been met. ${ }^{167}$ A more principled remedy would be to enjoin the conduct complained of with respect to the private actions, but we recognize that such a remedy is unlikely to be instituted, particularly when the investigation is undertaken by a domestic administrative tribunal in the complainant-import market. Of course, the provision of such a remedy at the bi-national panel level might be somewhat more attractive, if the bi-national panels were allowed to undertake a de novo review of any final determination undertaken by the administrative tribunal.

If a public practice is identified which is found actionable such that antidumping duties could be imposed, the remedy should promote the elimination of the public barrier to entry in the export-home market within a reasonably short period of time. Once again, a remedy allowing the binational panels to order the removal of the public barrier would be justified

165. "Every nation has some form of a state action doctrine and an act of state doctrine, exempting certain government acts from antitrust." Eleanor M. Fox, Competition Law and the Agenda for the WTO: Forging the Links of Competition and Trade, 4 PAC. RIM L. \& POL'Y J. 1, 21 (1995).

166. Once price discrimination is shown, the burden of proof could shift so that the respondent would have a chance to resist the finding of price discrimination on the basis that it represents a difference in cost structure.

167. We did suggest above that an "average variable cost" test would be more principled than the current "fully allocated cost" standard. 
if the bi-national panels were permitted to undertake a de novo review of the administrative panel determination. In any event, the respondent jurisdiction should have the option of eliminating the public' barrier to entry within a reasonably short period of time. The bi-national panels might be given the authority to an order rescinding the antidumping duty award, if the respondent government can establish that the impugned public practice has been eliminated.

\section{CONCLUSION}

The reversal of Canada's traditional trade policy position is unfortunate, and the objective of the elimination of antidumping practices should once again be pursued. The Canada-Chile Free Trade Agreement achieved this objective, and the negotiations underway between Canada and Costa Rica represent an opportunity to extend the precedent. In the alternative, the introduction of a market structure test would go a long way to reduce, if not eliminate, antidumping duties. This is due to the fact that findings of anticompetitive conduct are not easy to obtain. The inclusion of a market structure test based on the principles of the Brooke Group precedent has the collateral value of helping to establish competition law traditions and institutions in developing nations in Central and South America, and in the Caribbean, that likely could benefit from them.

In the leadership vacuum created by the growth of protectionist sentiment which appears to have existed in the United States over the past few years, the question arises whether Canada should be pursuing a much broader trade initiative. It appears that the FTAA initiative has fractured into a number of different trade initiatives in Central and South America. Using Costa Rica as an example of the kind of initiatives now underway, Costa Rica reached a free trade agreement with Mexico in 1994, the Dominican Republic in 1998, and Chile in December 1999. It is also involved in trade negotiations with El Salvador, Guatemala, Honduras, Nicaragua, and Panama, among other trade initiatives. ${ }^{168}$

There appears to be an opportunity to coordinate these trade initiatives into a "framework agreement" that could then form the basis of the negotiation with the United States for a Free Trade Agreement of the Americas, once the trade policy climate has improved. There clearly is a need to coordinate the various bilateral free trade agreements now existing between Canada, Chile, Costa Rica, and Mexico. The framework agreement could then be extended to include the various negotiating initiatives with other Central and South American trading partners.

168. See James D. Leach and Charles M. Gastle, Canada-Costa Rica Free Trade Initiative, Apr. 14, 2000 (submission to Canadian Dept. of Foreign Affairs and International Trade), available at http://www.esteycentre.ca/library.html. 
A significant precedent would be established if the framework agreement adopted the Canada-Chile Free Trade Agreement's approach to the elimination of antidumping practices. It is extremely unlikely that the United States would subsequently agree to an FTAA eliminating antidumping practices, but, at the same time, a principled approach to the elimination of antidumping practices should be taken when the opportunity presents itself. Alternatively, there may exist an opportunity to introduce a market structure test into a framework free trade agreement. This would be virtually impossible to achieve if the United States was a participant in the negotiations. 